\title{
O Simbolismo das Cores no Livro de José de Arimateia
}

\section{Pedro Chambel}

\section{OpenEdition}

Journals

\section{Edição electrónica}

URL: http://journals.openedition.org/medievalista/232

DOI: 10.4000/medievalista.232

ISSN: 1646-740X

\section{Editora}

Instituto de Estudos Medievais - FCSH-UNL

\section{Refêrencia eletrónica}

Pedro Chambel, «O Simbolismo das Cores no Livro de José de Arimateia », Medievalista [Online], 10 | 2011, posto online no dia 01 julho 2011, consultado no dia 19 abril 2019. URL : http:// journals.openedition.org/medievalista/232 ; DOI : 10.4000/medievalista.232

\section{(C) IEM}


Titulo: O Simbolismo das Cores no Livro de José de Arimateia. Autor(es): Pedro Chambel

Enquadramento Institucional: Membro do Instituto de Estudos

Medievais, FCSH-UNL

Contacto: pedrochambel@live.com.pt

Fonte: Medievalista [Em linha]. №10, (Julho 2011). Direc. José Mattoso. Lisboa: IEM.

Disponível em: http://www2.fcsh.unl.pt/iem/medievalista/

ISSN: 1646-740X

\section{Resumo}

O Livro de José de Arimateia, é um texto medieval, traduzido para português provavelmente no século XIII, e que constitui a primeira parte do ciclo da denominada Pós-Vulgata. Nele narra-se como o Graal, o cálice que conteria o sangue derramada por Jesus Cristo na cruz e recolhido por José de Arimateia, foi transportado de Jerusalém para a Grã- Bretanha, e as aventuras das personagens que ao longo da narrativa com ele se relacionam. No texto são citadas as cores branca, vermelha, verde, preta, azul e dourada que apresentam simbologias cuja interpretação revela-se de importância decisiva para a análise e compreensão de uma narrativa de marcado teor alegóricosimbólico. Pretendo, assim, contribuir para o estudo dos simbolismos das cores presentes nos textos medievais portugueses, como forma de análise dos mesmos, e suscitar a comparação dos significados propostos no estudo que efectuei com os presentes noutros textos da mesma época e com os que são transmitidos pelas cores presentes noutras formas de expressão da nossa Idade Média.

Palavras-chave: José de Arimateia; simbolismo; cores, Graal. 


\section{Abstract}

The Book of Joseph of Arimathea is a medieval text probably translated to Portuguese in the XIII ${ }^{\text {th }}$ century, wrote as the first part of the Post-Vulgate cycle. The book is a narrative about the Holy Grail, the chalice that was supposed to contain the blood shed by Jesus Christ while crucified, collected by Joseph of Arimathea; and also the adventures of the characters that interact with the grail while it was taken from Jerusalem to Great Britain. In this text there are references to several colors - white, red, green, black, blue and gold - which have symbolic meanings, that must be interpreted and taken into account on the analysis and comprehension of a narrative with a strong allegoric-symbolic content. Therefore, I intend to add a contribution to the study of the colors symbolism on Portuguese medieval texts, as an approach to their analysis, and give rise to a comparison of the meanings proposed by this study both with those of other texts written around the same time, and with other medieval forms of expression.

Keywords: Joseph of Arimathea, colors, symbolism, Holy Grail.

\section{O Simbolismo das Cores no Livro de José de}

\section{Arimateia}

\section{Pedro Chambel}

Pretendo com este estudo contribuir para a análise da simbologia das cores na Idade Média portuguesa, a partir das conotações que estas assumem num texto literário da época. Para tal, a fonte escolhida foi o Livro de José de Arimateia, o romance que constitui a primeira parte do denominado "Ciclo da Pós-Vulgata". Com origem em França, onde foi redigido entre 1230 e 1240, o texto foi traduzido para português por Fr. 
Joam Vivas, em meados do século XIII, segundo Ivo de Castro ${ }^{1}$. Utilizámos para o presente trabalho a edição paleográfica de Henry Hare Carter $^{2}$, a partir do único testemunho português da obra, presente no ms. 643 da Livraria do Arquivo Nacional da Torre do Tombo.

Ao longo da narrativa do Livro de José de Arimateia são citadas seis cores, o branco, o vermelho, o verde, o preto, o azul e o dourado, e ainda referenciado o prateado, embora esta última não se autonomize do metal cuja cor ostenta, como de resto, na maioria das citações, o mesmo sucede com a "cor de ouro".

Para iniciar o estudo, começarei por abordar dois episódios em que às cores branca, vermelha e verde são atribuídas, pelo narrador, conotações simbólicas e estas explicadas. O primeiro que surge na narrativa é o da sagração de Josefes, o filho primogénito de José de Arimateia, como primeiro bispo dos cristãos, em Sarrás, na véspera da entrada em batalha do rei Evalac contra os invasores egípcios. No texto, após ser aberto o tabernáculo onde se encontra o Graal por Josefes, e depois de este assistir a uma recriação da Paixão de Cristo e de os cristãos terem comungado no espaço denominado pelo profeta Daniel como o Paço Espiritual, o filho de José é vestido por anjos, de acordo com a dignidade que passa a exercer. Nesse momento, Deus explicalhe a propósito da sobrepeliz e da alva que, como são brancas, simbolizam, respectivamente, a castidade e a virgindade e que como esta última não pode existir sem a castidade, o bispo não pode vestir a alva se primeiro não envergar a sobrepeliz. Mais à frente é referido o capelo branco que simboliza a confissão, pois esta deve ser "a mais bramca cousa que seja e mais limpa", reportando-se assim o narrador à sinceridade e ao desejo de arrependimento que deve presidir à confissão, pois por ela o homem tornará a ser "limpo", uma vez perdoados e penitenciados os pecados outrora cometidos. O branco evoca pois o estado de pureza a que os cristãos aspiram pela confissão, assim como a castidade e a virgindade.

\footnotetext{
${ }^{1}$ Ibidem, pp.Ivo de Castro, "O Livro de José de Arimateia” in Dicionário da Literatura Medieval Galega e Portuguesa, Lanciani, G., Tavani, G., (dir.), Lisboa, Editorial Caminho, 1993, pp. 409,411.

2 The Portuguese Book of Joseph of Arimathea, Carter, H., (ed.), Chapel Hill, TheUniversity of North Caroline Press, 1967.
} 
No que respeita ao tecido verde das vestes do bispo, Deus explica a Josefes que ele não deve ser usado se o portador não tiver paciência, pois é essa a virtude que o tecido, por ser verde, transmite. E acrescenta que sem a paciência a vitória sobre o Inimigo jamais poderá ser alcançada, acrescentando, que, por cima do tecido referido, se põe outro branco que simboliza rectidão.

Por fim, no que respeita às cores, é referido o vermelho, a cor da casula, que simboliza a caridade que é como o fogo, quente e vermelha, e que deve transmitir, a quem a usa, a cobiça e a vontade de servir a Deus e de O amar e ao seu próximo ${ }^{3}$. Temos, assim explicado no texto o simbolismo do branco, do verde e do vermelho, encontrando-se o primeiro conotado com a virgindade, a castidade, a pureza e a rectidão, o segundo com a paciência e o terceiro com a caridade.

Iremos agora referenciar outro excerto do texto, onde as simbologias atrás expressas surgem confirmadas para as três cores, mas com nuances explicativas que convém sublinhar. Assim, quando a Nascião, encontrando-se na Ilha Tornante, surge-lhe a barca de Salomão, este, depois de nela entrar, vê em cima de um leito, três ramos de cores branca como a neve, vermelha como sangue e verde como a cor da esmeralda. Depois de os referir, o autor narra-nos a sua história, explicando a simbologia das cores mencionadas.

Assim, os três ramos pertencem à Árvore da Vida em três momentos diferentes da história do povo eleito, narrada no Velho Testamento. Inicialmente, e reportando-se ao Génesis, o narrador afirma que Eva trouxe do Paraíso um pedaço de um ramo da árvore que tinha o fruto proibido. Decidiu plantá-lo como forma de lembrança da ventura então perdida. O ramo pegou na terra e cresceu tornando-se branco, evocando deste modo a virgindade de Eva. Quando Deus ordenou a Adão e a Eva que procriassem, estes fizeram-no a uma sexta-feira e dormiram sob a Árvore que se tornou verde, pois Abel foi concebido com boa intenção e pensamento, e de forma casta e bondosa. $\mathrm{O}$ verde evoca assim, igualmente, a esperança da concepção e posterior reprodução do povo de Deus. No entanto, os ramos que tinham sido tirados da Árvore quando esta ainda era branca e que depois se desenvolveram na terra continuaram brancos. O narrador conta

\footnotetext{
${ }^{3}$ Ibidem, pp.118,119.
} 
depois a narrativa bíblica de Caim e Adão, e como o primeiro assassinou o segundo, de novo a uma sexta-feira, sob a Árvore da Vida. Antes, porém, refere como os sacrifícios feitos por Abel eram bem recebidos pela divindade e como o fumo que deles saía era branco e de bom odor. Como veremos, o branco é a cor da divindade e da hierofania, ou seja da sua manifestação, e por isso o fumo branco evoca a aceitação por parte da divindade dos sacrifícios de Abel e a comunhão entre ela e o primeiro filho de Adão e Eva.

Ora, após o assassínio de Abel, a Árvore tornou-se vermelha, em lembrança do sangue que sob ela foi derramada, assinalando o crime do primeiro homicida. No entanto, e mais importante para a análise da função do vermelho na obra, é o facto de o narrador afirmar que a morte à traição de Abel por Caim, evoca simbolicamente a morte de Cristo e a traição de Judas, consumada aquela também a uma sexta-feira. Assim, o vermelho é a cor do sangue derramado, mas ao remeter para a Paixão de Cristo adquire um simbolismo de morte redentora que, como posteriormente é dito, evoca a caridade de Cristo devido ao seu sacrifício para a salvação da humanidade.

Entretanto, os ramos que foram tirados da Árvore enquanto esta era verde e plantados, permaneceram da mesma cor e esta, tais como estes, sobreviveram ao Dilúvio, e continuaram a simbolizar a vida que depois continuou na Terra. Tendo Salomão decidido, por conselho da sua mulher, mandar construir a nau, foram nela depositados, em cima de um leito, três ramos de cores diferentes, extraídos da Árvore e dos seus rebentos. Ora, como referimos, a barca de Salomão surgiu a Nascião quando este se encontrava na ilha, para onde o levaram as mãos surgidas do céu e que o retirarem da prisão onde se encontrava. Abandonado, o cavaleiro pediu a ajuda divina e então surgiu, vindo do mar, um ancião numa barca ricamente ornamentada. Este explicou então o significado da nau e dos objectos que lá se encontravam. Assim, a nau simboliza a Igreja e o leito a cruz onde Cristo foi crucificado. Depois, o ancião afirma que o branco de um dos ramos significa a virgindade de Maria, o vermelho do outro ramo, a caridade de Cristo, manifestada ao se tornar homem e morrer na cruz para salvação da humanidade, enquanto o verde de esmeralda do terceiro simboliza a paciência que deve permanecer sempre verde no coração do cristão. As três cores correspondem, segundo o ancião, às três virtudes manifestadas por Cristo durante a vida e a Paixão, virgindade, caridade e paciência, e que lhe permitiram vencer o Diabo e redimir os homens, e às 
qualidades que os cristãos devem observar durante a vida para vencer o Inimigo e atingir o reino celeste ${ }^{4}$.

Assim, nas definições dadas pelo narrador, nos dois momentos referidos do Livro, o branco simboliza a virgindade, a castidade, a confissão, a rectidão e a pureza, o vermelho a caridade, remetendo para o sangue derramado por Cristo, enquanto o verde significa a paciência. Uma vez estabelecidos estes simbolismos, iremos analisar o surgimento das referências às cores noutros contextos da obra, começando com o branco.

Na visão do rei Evalac, que depois de baptizado passou a der denominado pelo nome de Mordaim, na véspera de defrontar em combate o exército de Tolomer, o monarca observou, na sua câmara, o surgimento de três árvores, de igual tamanho e grossura, sendo duas, como saberemos mais tarde, de cor branca como de cristal e a outra, a do meio, de cortiça. Da primeira vê sair gentes diversas, indo duas pessoas para uma negra gruta, seguindo-as depois a maioria das outras. Então, os que se encontram ainda fora da gruta começaram a partir a árvore de cortiça, permitindo ficar exposta a parte de dentro que era bela e também branca. Entretanto, da árvore cortada começou a sair sangue, do qual se banharam os poucos que ficaram fora da gruta, modificando, deste modo, a sua aparência ${ }^{5}$.

Ao decifrar a visão ao rei, Josefes explica-lhe que as três árvores representavam a Trindade, sendo as gentes que saíam da primeira os descendentes do primeiro homem e da primeira mulher, condenados ao Inferno, a cova negra, pelo pecado de Adão e Eva, os dois primeiros que se dirigiram para a gruta. A árvore de cortiça simboliza Jesus Cristo, que morto pelos homens derramou o sangue que salvou a humanidade, e no qual se banharam os justos. O interior branco de cristal que surgiu de dentro da árvore de cortiça, simboliza Cristo após a Ascenção, ou seja, após se ter juntado ao Pai e ao Espírito Santo, simbolizado pela terceira árvore, e de ter descido ao Inferno para resgatar as almas dos fiéis a Deus ${ }^{6}$. Temos, assim, que o branco é a cor da representação

\footnotetext{
${ }^{4}$ Ibidem, pp.208-224.

${ }^{5}$ Ibidem, pp.106-108

${ }^{6}$ Ibidem, pp.161-163.
} 
da divindade, enquanto o Inferno surge associado ao escuro e negro, que se contrapõe à claridade de cristal que emana das árvores brancas.

Vou-me agora reportar ao "cavaleiro branco" que surge na batalha entre os exércitos de Evalac e Tolomer. Antes do confronto, Josefes promete ao rei Evalac a vitória na batalha se ele se tornar cristão e dá-lhe um escudo onde pregou uma cruz feita de tecido vermelho, dizendo-lhe para o destapar quando se encontrasse em perigo. Durante o embate entre os exércitos dos dois monarcas, encontrando-se o rei de Sarrás ferido e na eminência de ser preso, ora a Deus prometendo-lhe a sua conversão e dos seus se Este o ajudasse, destapando depois o escudo que Josefes lhe deu. Vê então neste Cristo crucificado, deitando sangue dos pés e das mãos. Seguidamente, surge um cavaleiro de armas e corcel brancos, como de cristal, e de sinal vermelho, vindo de uma mata, que salva Evalac e posteriormente ajuda o cunhado do rei Serafes, depois baptizado com o nome Nascião, durante o combate, revelando-se decisivo na vitória dos súbditos do monarca de Sarrás sobre os invasores e na captura do rei inimigo. Ainda durante a batalha, o "cavaleiro branco" dá a Serafes uma acha dizendo que foi Jesus Cristo que lhe a enviou ${ }^{7}$.

Ora, o misterioso cavaleiro que surge na batalha e depois desaparece, de armas e cavalo brancos, trata-se de um ser das "hostes" de Cristo, assumindo-se, assim, como uma manifestação da divindade celeste no mundo dos homens, tratando-se portanto de uma hierofania. Como vimos, o branco é a cor que surge associada ao simbolismo da representação da divindade, e, neste caso, à sua manifestação na Terra, pelo que para o explicitar o cavaleiro surge na batalha de branco, enquanto o vermelho que é referido como presente na cruz do escudo de Evalac e no sinal do cavaleiro, remete para o sangue de Cristo, derramado durante a crucificação, e portanto para a fé cristã. Relembra, assim, o sacrifício do Filho de Deus e a nova "lei" que surgiu com ele. Ainda no que respeita ao aparecimento do cavaleiro branco que aparece para ajudar os futuros cristãos, relembro como nas batalhas na Península Ibérica contra as forças sarracenas, descritas, nomeadamente, na Crónica Geral de Espanha, quando aos cristãos se junta um cavaleiro "branco" que surge misteriosamente e decide a sua vitória, este é identificado com um santo, geralmente com S. Tiago, como também surge referido nos

\footnotetext{
${ }^{7}$ Ibidem, pp.142-145.
} 
milagres deste santo na versão portuguesa dos Autos dos Apóstolos. A este propósito o santo a quem Evalac, depois de convertido, dedicou a sua mais importante igreja, surgelhe e ao seu cunhado Serafes, após estes regressarem às suas terras, depois das aventuras na rocha e na ilha, andando sobre o mar e envergando vestes brancas ${ }^{8}$.

Uma nova manifestação da divindade associada ao branco, é referida na narrativa quando a Mordaim, estando na rocha que se encontra no meio do mar, surge uma pequena barca de prata e de vela branca, como a flor do lírio, com uma cruz vermelha. O rei encontrava-se desesperado por ter sido transportado para um local ermo, longe dos seus e sem recursos para se manter. É então que surge a barca e nela vem um formoso homem, como Mordaim nunca tinha visto, e que lhe diz ser capaz de transformar os feios em belos, os ricos em pobres e os sandeus em sisudos. Mordaim fala-lhe, confiante pela identificação da cruz da vela, e o homem bom reconforta-o, exortando-o a prosseguir na fé de Cristo, e aconselha-o a não desesperar, até que o rei acaba por adormecer ${ }^{9}$. Trata-se, de novo, de uma manifestação da divindade, que surge a Mordaim sob a forma de um homem, e o branco da vela e da barca de prata onde navega surge como um símbolo identificativo da divindade. Mais tarde, chega à ilha uma rica e negra barca com uma donzela, tratando-se de um diabo que vem tentar o rei a renunciar à fé que tinha abraçado. Surge, assim, uma dicotomia de cores, o branco associado a Deus e aos seres que $\mathrm{O}$ servem, e o preto associado ao Diabo e ao Inferno, como referimos quando mencionámos a cova negra que simboliza o local de perdição das almas, à qual se associam as dicotomias Bem/Mal, Salvação/Eterna Condenação, Puzeza/Pecado, que se expressam, igualmente, na oposição entre a luminosidade e a escuridão. A este propósito, quando o narrador é levado pelo anjo para ter a visão da Trindade, ele encontra-se num local mais claro e branco que o marfim.

Note-se ainda que, tanto o cavaleiro branco, como a vela da barca de prata, ostentam um sinal vermelho, no caso desta última uma cruz, que remetem para o sangue de Cristo, e portanto para a salvação da humanidade pelo sacrifício de Cristo, identificando a crença na nova fé.

\footnotetext{
${ }^{8}$ Ibidem, pp. 271,272.

${ }^{9}$ Ibidem, pp.174-176.
} 
O branco também surge referido quando, encontrando-se ainda Mordaim sozinho na ilha, desesperado e com fome, após ter sido tentado pelo diabo, encontra um pão negro de cevada e decide comê-lo. Quando o mete na boca, ouve um ruído que se assemelha ao que seria produzido por todas as aves do mundo, e quando olha para cima vê uma espantosa ave com a cabeça negra como pez, os olhos e os dentes vermelhos como o fogo, a cabeça semelhante à de uma serpente, o pescoço de águia e as penas das asas brancas como a neve, assim como as da parte de trás do corpo, que fere o rei e o impede de comer o pão. Ora, depois de descrita a origem fabulosa da ave, o narrador afirma que ela surge sempre para espantar os que servem a Deus ${ }^{10}$. A ave é constituída, quer por cores e seres associados à divindade, o branco, o vermelho e a águia, quer por um animal e uma cor que remetem para as forças do Mal, como é o caso da serpente e do preto.

No seguimento da narrativa, apercebemo-nos que o pão negro surgiu a Mordaim como uma tentação a que ele devia resistir. Na verdade, depois de ser impedido de comer pela ave e por esta ser ferido, e de ter desmaiado, acorda saciado como se tivesse ingerido os melhores manjares do mundo ${ }^{11}$. Assim, a ave impede o rei de cair na tentação a que foi submetido. Penso que este episódio se relaciona com o milagre de S. Bento que relata como o santo ordenou a um corvo, ave de cor negra, que costumava alimentar, que levasse para longe um pão envenenado que lhe tinha sido oferecido, e que surge nos Diálogos de S. Gregório, analisado na minha dissertação de doutoramento ${ }^{12}$. É certo que há diferenças nas narrativas, mas têm em comum o facto de serem referenciadas aves com conotações que tanto remetem para o Bem como para o Mal. No caso do corvo, ele tanto é associado ao primeiro animal que tendo sido enviado por Noé após o Dilúvio, não voltou à arca porque sendo necrófago alimentou-se dos homens e animais mortos, como à ave que providenciou o alimento ao profeta Elias. O fabuloso animal que impede Mordaim de comer também tem elementos que remetem para pólos de significação simbólica opostos, como referi. E nos dois episódios é ao serviço da divindade que as aves actuam, uma vez que foi esta que inspirou o S. Bento, de forma a

\footnotetext{
${ }^{10}$ Ibidem, pp.184,186.

${ }^{11}$ Ibidem, pp186,187.

12 Pedro Chambel, Os Animais na Literatura Clerical Medieval Portuguesa dos Séculos XIII e XIVPresença e Funções", Lisboa, dissertação de doutoramento, Faculdade de Ciências Sociais e .Humanas da U. N. L., 2003, pp.54,55.
} 
que se apercebesse da tentativa de homicídio. Assim, as duas aves que apresentam elementos antagónicos a nível de significação e de identificação simbólicas, afastam, nas duas narrativas, o perigo de homens crentes e que se encontram ao serviço de Deus.

Ora, nas narrativas medievais de origem clerical os relatos de intervenções divinas remetem para milagres presentes, quer na Bíblia, quer nos textos hagiográficos mais conhecidos, como forma de os relembrar, mas também para ajudar a identificar uma determinada acção como veiculada pela vontade de Deus. Penso, portanto, que se pode interpretar a narrativa da ave compósita do Livro de José de Arimateia como relembrando a do milagre de S. Bento com o corvo, que Jacques Voisenet associa ao da narrativa bíblica da ave que alimentou Elias ${ }^{13}$.

No que respeita ao simbolismo do branco presente na ave, ele assinala que o rei encontrava-se protegido pela divindade, pois é o aparecimento do animal que evita que Mordaim caia na tentação de se alimentar do pão negro que lhe estava interdito. Mas a ave assusta e espanta o rei, surgindo-lhe portanto associados elementos com conotações negativas que causam o assombro a Mordaim.

Irei agora referir dois episódios que se assemelham. Em ambos, surgem do céu mãos brancas que salvam dois dos protagonistas do Livro e eleitos de Deus, Nascião, primeiro, e seu filho Celidones, depois. No que respeita ao cavaleiro, quando se encontra no cárcere, apercebe-se duma grande e surpreendente claridade, e quando olha na direcção do céu vê uma nuvem vermelha, da qual surge uma mão branca com a manga vermelha como o fogo. A mão pega em Nascião e leva-o da prisão pelo ar até à Ilha Tornante onde encontrará a nau de Salomão.

No que respeita a Celidones, ele é retirado da torre, onde se encontrava preso e ameaçado de morte, por nove mãos brancas que surgem do céu e o afastam do perigo, levando-o para uma costa perto de onde o pai se encontrava ${ }^{14}$. Em ambos os casos tratase da providência divina que salva Nascião e Celidones, materializando-se esta sob a forma de mãos gigantescas que surgem do céu, e cuja cor remete para a intervenção de Deus no percurso terreno de dois dos eleitos da narrativa do Graal. No primeiro caso, ao

\footnotetext{
${ }^{13}$ Ibidem, p.55.

${ }^{14}$ O Livro de José de Arimateia, pp.191-195, 199, 225.
} 
branco surge associado o vermelho da manga associando-se assim o simbolismo da nova lei à hierofania. Posteriormente, poderemos constatar que ao vermelho se associa também outro simbolismo da nuvem desta cor quando analisarmos a simbologia do vermelho.

Na Ilha Tornante, Nascião tem uma visão, depois de orar e pedir a protecção a Deus contra as tentações do Demónio, na qual surgem várias aves brancas. Destas, destaca-se uma, maior, mais bela e que voa acima das outras, que ergue Nascião e o ensina a voar. Depois diz-lhe que tem fome e o cavaleiro responde-lhe que lhe dará o que ela desejar. Então, a ave afirma querer o coração de Nascião e ele oferece-lho, dizendo o animal que aquele é o pequeno coração do grande leão donde sairá o que por feitos da força do corpo e dos membros vencerá e submeterá as bestas nuas, por vontade divina, e depois aprenderá a voar por cima das altas montanhas e atingirá o Céu ${ }^{15}$.

As aves são um símbolo, quer da divindade, quer dos eleitos desta, e o voo significa o romper com as tribulações terrenas, e a ascensão dos fiéis para o reino celestial. O branco como vimos, é a cor da pureza que se alcança pelo baptismo, pelo que as aves brancas que voam remetem para os crentes na fé de Cristo, limpos do pecado. Mas uma ave destaca-se, a que voando mais alto pede o coração de Nascião. Esta é uma figuração da divindade que pede ao cavaleiro que se lhe entregue na fé de Cristo. Fá-lo ensinandoo primeiro a voar, que simbolicamente constitui a condição para se alcançar o mundo do divino e dos eleitos de Deus. Depois oferece-lhe o coração, significando o acto de comunhão com o divino e a reafirmação da sua fé, depois de se ter baptizado e mudado de nome ainda em Sarrás.

No que respeita à ave chamar-lhe leão e à predição que lhe faz, o cavaleiro é comparado ao animal que simboliza a bravura e a nobreza, enquanto que o que vencerá as nuas bestas, ou seja, os pecadores e não crentes, e que no final da vida aprenderá a voar, reporta-se a Galaaz, o último cavaleiro da linhagem de Nascião, que vencerá sempre os seus oponentes e verá as maravilhas do Graal, e que se elevará após a morte até ao reino celeste.

\footnotetext{
${ }^{15}$ Ibidem, pp. 202,203.
} 
Entretanto, perto do mar, para onde foi levado pelas nove mãos brancas, o filho de Nascião, Celidones, decifra os sonhos do rei da Pérsia, Label, levando à sua conversão. Num deles, Label viu uma serpente que voava até ao Mar Vermelho, e depois de nele mergulhar saía transformada num pombo branco. Segundo Celidones, a serpente simboliza o rei que, sendo pagão e pecador, serviu até então o inimigo de Deus e portanto é representado pelo réptil, que é um símbolo do pecado e do próprio Demónio. O Mar Vermelho simboliza as águas baptismais, explicando o jovem que, assim como Deus salvou os israelitas do jugo do faraó, abrindo-lhes a passagem no mar, pelo baptismo Cristo salva os pecadores arrependidos, libertando-os da mácula do pecado. $\mathrm{O}$ vermelho do mar simboliza o sangue derramado pelo Filho de Deus na cruz. Assim, Label sai do mar figurado em pombo branco, um animal conotado, não só com os fiéis, como com o próprio Espírito Santo, enquanto a cor branca reporta-se ao novo estado de Label, perdoado pelo baptismo, simbolizado pelo Mar Vermelho, dos pecados cometidos e convertido à fé de Cristo. Mais tarde, depois de ter sido baptizado por um ermita, o rei dos persas opta por vestir panos brancos, assinalando, assim, o seu estatuto de baptizado e de crente em Jesus, vindo a abandonar os súbditos que recusaram seguir a fé em Cristo ${ }^{16}$.

Na Vida de Santa Pelágia, encontramos um episódio similar, quando o bispo Nono, num sonho, antevê a conversão da meretriz Pelágia ao ver uma pomba suja mergulhar numa pia baptismal e de lá sair limpa e branca, reportando-se a cor ao estado de pureza que Pelágia alcançou pelo baptismo e pela posterior vida exemplar à qual se dedicou ${ }^{17}$.

Ora, também o duque Ganor tem um sonho com pombos brancos. Neste caso as aves seguem um caminho, e a dada altura uma nuvem torna-os negros e entram num vale escuro no qual alguns dos pombos ficam retidos. Josefes explica o sonho ao duque dizendo-lhe que os animais significam os cristãos que com ele e seu pai vieram de Jerusalém, limpos dos pecados pelo baptismo. No entanto, durante o trajecto que os levou à Grã-Bretanha, pecaram, perdendo então a "branquedumbre" das boas obras, pelo que no sonho surgem figurados com a cor negra, simbolizando o vale escuro o

\footnotetext{
${ }^{16}$ Ibidem, pp. 233,238 .

${ }^{17}$ I. Castro, (apres.), "Vidas de santos de um manuscrito alcobacense: vida de Tarsis, vida de uma monja, vida de Santa Pelágia, morte de S. Jerónimo, visão de Túndalo”, Revista Lusitana, Lisboa, Nova Série, nº (1982-1983), p.23.
} 
Inferno $^{18}$. A simbologia do branco reporta-se à que apontámos anteriormente, evocando o estado de pureza e de limpeza de pecados que o baptismo proporcionaria. O negro e o escuro, por oposição, remetem para o pecado e para o Inferno, manifestando-se mais uma vez a oposição claro/escuro, que simboliza a que se estabelece entre o bem e o mal, e a pureza e o pecado.

O branco surge ainda como a cor de um cervo que, ladeado por quatro leões, surge a José de Arimateia e aos seus companheiros, indicando-lhes o caminho a seguir, depois de todos terem orado, pedindo a Deus que lhes desse um sinal, para que soubessem o que fazer para atravessar um caudaloso rio. O cervo branco surge com uma cadeia de ouro e a sua pacífica convivência com os leões causa natural estranheza aos que o vêem. Já no meu estudo sobre a simbologia dos animais na Demanda do Santo Graal dediquei uma análise à presença destes animais na dita obra que é a terceira e última parte do ciclo da Pós-Vulgata de que o Livro de José de Arimateia é o primeira. Neste é Josefes que explica o simbolismo dos animais, dizendo que o cervo deve ser entendido como Jesus Cristo, remetendo o branco para a virgindade que sempre manteve, enquanto a cadeia de ouro simboliza a humildade e os quatro leões os evangelistas ${ }^{19}$.

Finalmente, menciono como o branco surge no romance para identificar uma abadia cisterciense que teria surgido na Grã-bretanha menos de um ano após Mordaim e a sua mulher se terem retirado para uma ermida de um homem bom, e que estaria na origem da formação da referida abadia ${ }^{20}$. A associação da ordem de Cister à elaboração do ciclo do Graal foi proposta inicialmente por Étienne Gilson e poderia explicar a referência aos monges brancos no Livro de José de Arimateia, que se reporta aos primeiros anos do cristianismo. De qualquer forma, trata-se de uma forma de prestigiar a ordem que assim surge ligada à história do Graal e à implantação do cristianismo no Ocidente medieval europeu. Mas, já antes no texto é mencionado no texto um frade que surge vestido com uns panos brancos, o que poderá indicar que se trataria de um cisterciense.

Em suma, o branco é a cor associada à divindade celeste e à sua manifestação no mundo dos homens, à virgindade e à castidade, à Trindade, à pureza, à rectidão e à ausência do

\footnotetext{
${ }^{18}$ O Livro de José de Arimateia, pp297,298.

19 Ibidem, pp.338,339,340,341.

${ }^{20}$ Ibidem, pp.324
} 
pecado. É ainda a cor dos eleitos e dos servidores de Deus que com as vestes brancas se identificam como tal, reportando-se aos fiéis limpos dos pecados pelo baptismo, apresentado, assim, uma simbologia positiva.

Irei agora abordar as referências ao vermelho na narrativa que ainda não analisei. Esta cor, como vimos, remete para o sangue de Cristo, vertido na cruz e, por extensão, para a purificação transmitida pelo baptismo, simbolizado no Livro pelo Mar Vermelho. Ora, o Graal é precisamente o cálice onde se encontra o sangue do filho de Deus, recolhido por José de Arimateia aquando da Paixão, e a sua história é a narrativa da sua ida de Jerusalém para a Grã-Bretanha e as aventuras da sua busca nesta última, após o advento da nova cavalaria, que o Livro de José de Arimateia filia nos peregrinos idos com o Graal de Jerusalém e Sarrás e nos nobres convertidos nas ilhas britânicas. Deste modo, o vermelho adquire um valor relevante na narrativa. No entanto, como veremos, outros simbolismos encontram-se associados a esta cor.

Já nos referimos ao escudo que o rei Evalac recebeu de Josefes e que nele colocou uma cruz vermelha feita de pano e que durante a batalha com os invasores egípcios, depois de Evalac o ter destapado, viu nele uma imagem de Cristo crucificado que parecia verter sangue das mãos e dos pés. Ora, depois da batalha, o rei mostra a Josefes o escudo onde de novo surge a mesma imagem e que milagrosamente faz sarar de um braço cortado um dos súbditos de Evalac, levando o cunhado deste, Serafes, a querer aderir à fé de Cristo $^{21}$. Deste modo, o vermelho associa-se às propriedades de cura e milagre que a imagem do Salvador e do seu sangue proporciona.

Mas também surge como a cor da vingança e da justiça divina. Assim, quando Josefes impede um demónio de se apossar das almas dos que, em Sarrás, não quiseram ser cristãos, surge-lhe um anjo de rosto como de fogo que lhe enfia uma lança na perna por ele ter deixado de baptizar os fiéis para acudir aos que renegaram a sua fé ${ }^{22}$. Mais tarde Nascião reporta-se ao anjo como o "anjo vermelho". Mas o sangue, como vimos, também tem a propriedade de curar, e é do que sai da lança que feriu Jesus Cristo e

\footnotetext{
${ }^{21}$ Ibidem, pp.128,129,142,154.

${ }^{22}$ Ibidem, p. 157.
} 
posteriormente Josefes, que sara Nascião da cegueira que o afectava após ter levantado o pano que cobria o Graal para ver as suas maravilhas ${ }^{23}$.

A justiça divina também se manifesta na nuvem vermelha da qual sai a mão que liberta Nascião, uma vez que ela depois desce sobre o cavaleiro que o tinha prendido, de nome Calafer, e dela sai o pé e a mão "do que nela andava" e que ferem Calafer na face. Posteriormente, surge-lhe na parte direita desta um sinal vermelho que arde como fogo, sendo este feito pela mão que saiu da nuvem, e na parte esquerda um sinal negro que transmite a Calafer o frio de geada. O seu padecimento irá prosseguir até Celidones ser libertado, com novos sofrimentos até morrer debaixo dos destroços da torre onde se encontrava preso o filho de Nascião, após ter surgido a escuridão que antecede a voz que anuncia a vingança divina sobre os inimigos de Deus ${ }^{24}$. Assim, é da nuvem vermelha que surge a mão branca que liberta Nascião, mas também é a partir dela que a divindade castiga Calafer, ficando neste o sinal vermelho que simboliza a cor do fogo que lhe arde na face.

Quando Nascião, estando na ilha Ilha Tornante, decide embarcar na nau de Salomão, depara-se com objectos e signos vermelhos, como é o caso das letras vermelhas que se encontram na bainha da espada que avisam que ela só pode ser empunhada por Galaaz, o cavaleiro eleito para descobrir as maravilhas do Graal, descendente de Salomão, e do próprio Nascião. Ora é atribuído ao rei de Israel o desejo da confecção da nau, e este toma precauções para que a espada que lá colocou apenas possa ser usada pelo cavaleiro a quem ele a destinou, caso contrário, incorrerá na vingança divina. Assim, as letras que surgem na bainha da espada são vermelhas, como da mesma cor são a própria bainha, da cor da rosa, e a espada, vermelha como o sangue, que possui letras negras como carvão que dizem que a arma apenas serrvirá aquele a quem está destinada ${ }^{25}$. Neste sentido, o vermelho surge associado aos avisos proféticos de Salomão, que afirmam que os objectos desta cor apenas podem ser utilizados pelo último homem da sua linhagem, ao mesmo tempo que remetem para o maravilhoso cristão ao exibirem a cor associada ao sangue derramado por Cristo e à linhagem do rei, à qual a tradição associou a da Virgem. O vermelho associa-se, no caso das letras, da espada e da bainha, ao

\footnotetext{
${ }^{23}$ Ibidem, pp.158-160.

${ }^{24}$ Ibidem, pp.192-195.

${ }^{25}$ Ibidem, pp.207,208.
} 
simbolismo da justiça divina, do sangue de Cristo e à sua fé, assim como à transmissão linhagística que o sangue evoca, enquanto o vermelho cor de fogo da espada remete para as proezas de cavalaria, nomeadamente para as que estão destinadas a ser realizadas pelo último descendente de Salomão, uma vez que o vermelho também é a cor que evoca os feitos guerreiros e as batalhas. Note-se que se encontra na barca de Salomão, que simboliza a Igreja, um pano branco que cobre, como cortina, o leito a cujos pés se encontra a espada ${ }^{26}$, e que remete, como já vimos, quer para o divino, quer para a pureza e a virgindade, que irá caracterizar o cavaleiro a quem a espada é destinada, Galaaz.

Outras cores surgem associadas à nau de Salomão, mas faremos a análise da sua presença quando a elas nos referirmos.

Mais tarde, Nascião, depois de se deslocar até à costa, para onde uma voz num sonho lhe disse para ir a fim de embarcar numa nau, e ter de novo encontrado a barca de Salomão, à beira da qual é sujeito a uma tentação de um diabo, adormece após orar e ouvir as vozes demoníacas. Surge-lhe, então, num sonho, um homem com vestes vermelhas que lhe anuncia que ele, Celidones, José e Josefes com os seus seguidores irão para a terra prometida, a Grã-Bretanha, onde irá surgir a nova cavalaria cristã, e como o derradeiro cavaleiro da sua linhagem irá a Sarrás com o Santo Graal ${ }^{27}$. Ora, o vermelho das vestes do homem que fala a Nascião evoca a fé de Cristo, simbolizada pela cor do seu sangue. Trata-se de uma aparição provinda da divindade, que num sonho se manifesta a Nascião, apresentando-se com as cores da nova fé.

Quando o homem bom parte, Nascião apercebe-se que lhe deixou uma carta na mão, que dizia que nela veria os nomes dos seus descendentes. Continuando a sonhar, o cavaleiro tem a visão do filho, dos leões e do cão que simbolizam os reis e cavaleiros que dele virão. Ora, quando acorda encontra a carta que, em letras vermelhas em hebraico e em latim, referencia os descendentes de Nascião ${ }^{28}$. A cor das letras remete para o facto de nelas se expressar a linhagem do cunhado de Mordaim, cujo vermelho simboliza, mas também se reporta a Cristo de quem os seus descendentes serão devotos,

\footnotetext{
${ }^{26}$ Ibidem, p.206.

${ }^{27}$ Ibidem, pp.280,281.

${ }^{28}$ Ibidem, pp. 281,282.
} 
mesmo Lancelote, que no final da vida se arrependerá dos seus pecados indo para uma ermida. Mas, penso que ao surgirem com a cor vermelha, as letras sublinham também que o que por elas é transmitido é uma comunicação da divindade que tem como destinatário Nascião, sendo, como já assinalámos, a cor que simboliza a nova aliança de Deus com os homens.

O vermelho tem um simbolismo bem diferente na visão do duque Ganor, quando sendo ainda uma criança pobre, guardadora de vacas na Galileia, observou um alto lírio, à sombra de um rosal. Ao observar a flor, pareceu-lhe que o rosal saía do lírio como se nele estivesse enxertado, e que as rosas que o formavam eram feias. Seguidamente saiu da flor um líquido vermelho e espesso que se espalhou pelas rosas fazendo-as murchar. Depois, surgiu uma nova rosa, bela e mais vermelha que as outras. Esta permaneceu fechada durante nove dias, ao fim dos quais saiu da flor, que continuava fechada, uma figura de homem que defrontou e venceu uma serpente, dirigindo-se depois para o lírio onde colheu as folhas do rosal, levando-as consigo.

Explicando ao duque a visão que este teve, Josefes diz que o lírio simboliza Eva. Ora, sendo o lírio uma flor branca, significa que a primeira mulher era pura antes de cometer o Pecado Original, simbolizado pelo espesso líquido vermelho. As rosas feias remetem para os profetas e homens bons que nasceram antes do advento de Cristo e que, portanto, foram para o Inferno. Quanto à bela rosa, mais vermelha que as outras e que permaneceu fechada, trata-se da mãe de Jesus, que manteve a virgindade, enquanto a figura de homem é uma representação de Cristo que matou a serpente, ou seja, segundo a explicação de Josefes, venceu a morte, redimindo assim a humanidade. No que respeita ao rosal, ele simboliza o mundo terreno, pois possui espinhos, que remetem para os pecados que nele os homens cometem ${ }^{29}$.

Temos, assim, que o vermelho adquire simbolismos diferentes na visão do duque Ganor. Por um lado, e de forma positiva, é a cor das flores que representam os profetas e homens bons que viveram antes da Paixão, e da rosa que simboliza a Virgem. Por outro lado, apresenta uma simbologia negativa, ao remeter para o Pecado Original. No entanto, o narrador acentua o facto da rosa que representa a Virgem ser mais vermelha

\footnotetext{
${ }^{29}$ Ibidem, pp.299-303.
} 
que as outras, distinguindo-se delas pela intensidade da cor, sugerindo, assim, que esta característica remete para uma simbologia mais positiva.

O vermelho surge ainda associado ao sangue de doze companheiros de Josefes, incumbidos de propagar a fé cristã pelas Ilhas Britânicas e que são martirizados junto de uma cruz que passa a ostentar o seu sangue. Depois de o senhor da terra, responsável pelos martírios e de fazer arrastar uma cruz, endoidecer e matar-se, após ter assassinado a mulher e o filho, Josefes passa pela terra e manda enterrar perto da cruz os seus antigos companheiros. Não obstante ter mandado lavar o sangue da cruz, esta permaneceu escura, ostentando miraculosamente a cor do sangue derramado pelos mártires ${ }^{30}$. Neste sentido, o vermelho relembrará para sempre o sacrifício a que foram sujeitos os propagadores da fé cristã, cujo número remete simbolicamente para o dos evangelistas.

O vermelho associa-se, igualmente, à preservação da memória no caso do escudo de Mordaim, quando a este Josefes anuncia que morrerá em breve. O rei, estando na ermida, pede-lhe que lhe deixe uma lembrança que o reconforte da ausência do amigo. Josefes pede-lhe então o escudo que lhe tinha dado para o ajudar na batalha contra os invasores de Sarrás. Logo que Mordaim o mostra, Josefes começa a sangrar do nariz, e com o sangue faz-lhe o sinal da cruz. Depois anuncia-lhe que esta se manterá sempre vermelha enquanto o escudo durar e que será usado por Galaaz ${ }^{31}$. O escudo que começou por ostentar o pano vermelho que recordava o sacrifício de Cristo e que durante a batalha mostrou num vermelho vivo a imagem de Cristo crucificado, passou depois a ostentar o sangue do primeiro homem que se responsabilizou pela guarda do Graal, e que foi eleito pela própria divindade como o primeiro bispo cristão. Neste sentido, o vermelho surge associado ao sangue de um eleito, enquanto a cruz remete para a fé em Cristo.

É com este último significado que as cruzes surgem na narrativa com a cor vermelha. Registamos, assim, como a fim de assinalar a presença de Celidones no castelo do duque Ganor que se encontra na origem da sua futura conversão, a fortaleza é assinalada

\footnotetext{
${ }^{30}$ Ibidem, pp.324-326.

${ }^{31}$ Ibidem, pp.366,367.
} 
por uma cruz vermelha, indicando a Josefes que nela poderá entrar com os seus companheiros $^{32}$. Também é esta a cor das letras pela qual a divindade transmite o nome a ser dado ao castelo que passará a guardar o $\mathrm{Graal}^{33}$.

Em suma, o vermelho surge na narrativa remetendo para a crucificação e para a nova aliança de Deus com os homens, relembrando-a, normalmente em forma de cruz, e remetendo, neste sentido, para a caridade divina e para a água do baptismo. Mas é também uma das cores usada para assinalar a comunicação do Além com os homens, a justiça da divindade e a punição efectuada por esta. Surge na narrativa, igualmente, como a cor que simboliza a linhagem, a Virgem e os feitos guerreiros, e que se associa à preservação da memória do sangue derramado pelos crentes. Por fim, e com uma conotação negativa, é o símbolo do Pecado Original.

Iremos agora analisar as referências ao verde na narrativa e tentar perceber o simbolismo desta cor. Como vimos, o verde associa-se, segundo nos é explicado pelo próprio texto, à paciência. Mas, a partir das mudanças de cor da Árvore da Vida, que se torna verde após Adão e Eva terem concebido sob ela Abel, obedecendo assim ao desígnio de Deus, o verde surge conotado com o início da linhagem dos homens, e à esperança na renovação e propagação do género humano que irá originar uma nova aliança entre os homens e a divindade, embora aqueles ainda se encontrem com a mácula do pecado de Adão e Eva. Refira-se que, simbolicamente, Abel surge associado a Cristo e o seu assassinato pelo irmão à traição de Judas. Ora, desta forma o nascimento do filho de Adão e Eva, no plano simbólico, anuncia o de Jesus, o que reforça a ideia de esperança associada à cor que a árvore da Árvore da Vida ostenta após a concepção de Abel.

Na sagração de Josefes como o primeiro bispo da Cristandade, um dos anjos que lhe surge traz a escudela com o sangue de Cristo metida numa pedra verde como a da esmeralda. Com este anjo encontravam-se outros dois, um trazendo incenso, mirra e outras especiarias, e o outro empunhando uma espada de metais preciosos e com o ferro com a cor do fogo. Assim, o verde surge associado ao Graal ${ }^{34}$. Ora, penso que a

\footnotetext{
${ }^{32}$ Ibidem, p. 295 .

${ }^{33}$ Ibidem, p.370.

${ }^{34}$ Ibidem, pp.114,115.
} 
conotação do verde com a ideia de renovação, associado à espada que simboliza a soberania divina e terrena, remete neste momento da narrativa para o anúncio de uma nova era que o Graal trará para a Cristandade, nomeadamente associada ao surgimento de uma nova cavalaria que se guiará segundo os ideais cristãos, fazendo assim convergir a necessidade de justificação da sociedade cavaleiresca da época com a ideologia que o clero professava. Na verdade, a possível associação dos monges de Cister ao processo de cristianização da história do Graal, pode justificar esta hipótese. De qualquer forma, ao longo do ciclo da Pós-Vulgata assistimos ao nascimento de uma cavalaria, que surge enquadrada pelos ideais cristãos, nas Ilhas Britânicas, e cuja origem se encontra relatada no Livro de José de Arimateia, e que irá substituir a pagã. Da mesma forma irá surgir uma nova soberania terrena, de que Artur é o modelo, ainda que imperfeito. Deste modo, ponho a hipótese de, simbolicamente, o verde da pedra do Graal associado à espada, anunciar neste contexto o surgimento da nova sociedade cavaleiresca, sendo que o verde é a cor tradicionalmente associada ao $\mathrm{Graal}^{35}$.

Nos dois sonhos do rei Label, decifrados por Celidones, o verde apresenta simbologias diferentes. Assim, no primeiro, o rei sonha com um prado verde no qual se encontra uma panela cheia de terra e cercada por flores, donde depois sai uma serpente que com o bafo queima tudo o que a rodeia. Explicando o sonho ao soberano, Celidones diz-lhe que o prado verde simboliza o mundo, cuja verdura apraz aos homens que cometem pecados mortais e que vivem para usufruir os prazeres mundanos. A transitoriedade associada ao mundo e aos prazeres que proporciona é referenciado por Celidones que assinala como, durante a noite, tudo nele murcha e seca, comparando-o ao corpo humano. Refiro, ainda, como o filho de Nascião assinala como é efémera a beleza das flores excepto de uma, a que simboliza a Virgem que jamais perdeu a "bramquejumbre" da sua virgindade, numa associação da cor branca que já mencionámos ${ }^{36}$.

No outro sonho, ao rei persa surgem-lhe dois caminhos. Um é estreito mas com muitas árvores de fruto e com um tanque no meio onde um formoso homem lava os pés, vendose ao longe uma bela e grande cidade. O outro, pelo contrário é largo e negro, encontrando-se trilhado e cheio de ladrões. Ora, segundo Celidones, este é o caminho do

\footnotetext{
35 Gerd Heinz-Mohr, Dicionário dos Símbolos - Imagens e Sinais da Arte Cristã, São Paulo, Paulus, 1994, p.339.

${ }^{36}$ O Livro de José de Arimateia, pp.228-230.
} 
Inferno, enquanto o primeiro "que era verde" significa a nova lei, que permite alcançar o Paraíso, sendo necessário para o percorrer o baptismo na água que o tanque evoca, simbolizando as árvores os apóstolos e os prelados ${ }^{37}$.

Temos, assim que o verde apresenta um simbolismo com conotação negativa ao remeter para o mundo e para os pecadores, e positiva significando a fé em Cristo. A estes simbolismos acrescentam-se os que atrás referimos, ou seja, o da paciência, do Graal, da renovação e da esperança nesta.

No que respeita ao simbolismo da cor preta que agora iremos analisar, já vimos como ele se expressa na narrativa remetendo para o mundo ctónico do Inferno e seus seres e para o pecado. O negro, o escuro, opõe-se à luz e ao claro que remete para a divindade celeste. É neste dualismo que se expressa a cor preta que remete para a ausência de luz e, simbolicamente, de esperança na salvação. Mas é também a cor que indica o resultado da punição de Deus cuja justiça envia os descrentes e os pecadores para a eterna condenação, marcando-os com o sinal punitivo da cor preta. Assim, ao abordarmos esta não a podemos dissociar das referências ao negro e ao escuro que remetem para o mesmo simbolismo.

Nos outros trechos da narrativa não encontramos grande variação ao que já adiantámos. Assim, na visão que o rei Evalac tem na sua câmara em que vê os três ramos que representam a Trindade, a cova negra para onde se dirigem as figuras humanas após o pecado de Eva, representa o Inferno a que a humanidade estava destinada até à redenção que a vinda de Cristo tornou possível para os justos e crentes da nova fé $\mathrm{e}^{38}$. No mesmo sentido, no sonho do rei Label a casa negra e feia, de cujo interior se ouvem brados, com que termina a estrada larga habitada por ladrões, é o Inferno a que o rei persa estaria destinado caso se não se convertesse ${ }^{39}$. Ora, o mesmo motivo da casa escura num fundo vale onde a luz se encontra ausente e donde são emitidos sons de prantos surge no sonho do duque Ganor como estando destinada aos pecadores, referenciando do mesmo

\footnotetext{
${ }^{37}$ Ibidem, pp.230-233.

${ }^{38}$ Ibidem, pp.106,162.

${ }^{39}$ Ibidem, p. 231 .
} 
modo o local da condenação eterna ${ }^{40}$. Neste sentido, o Inferno surge referido como um local escuro, negro, fétido e donde são emitidos os gritos de sofrimento dos condenados.

Quando Mordaim se encontra na rochosa ilha sofre duas tentações demoníacas. Assim, vê surgir, vinda do seu lado esquerdo, uma nau de vela e cortina pretas, da qual, após aportar, sai uma donzela bela que lhe fala das atribulações e sofrimentos que o rei passou após se ter convertido à fé de Cristo, e promete-lhe fazê-lo senhor das suas riquezas e do seu poderio, se ele a renunciasse. Perante a hesitação do rei, diz-lhe que sem a sua ajuda o monarca jamais voltará ao seu reino. Mantendo-se o mutismo do rei, a donzela afasta-se na nau, acompanhada de uma tempestade que parecia levar a barca para o abismo ${ }^{41}$.

Ora, depois deste acontecimento, o rei de Sarrás pensa no sucedido e de tudo o que aconteceu após abraçar a fé de Cristo. Então, desesperado, vê na rocha um caminho que o leva até uma cova negra. No entanto, no momento de lá entrar, desmaia e sente que um homem o ergue pelos cabelos. Quando acorda vê que a porta da gruta se encontra encerrada e depois surge-lhe a nau de prata a que nos referimos atrás ${ }^{42}$. Este episódio revela o que teria acontecido ao rei se a tentação tivesse tido efeito e cedido ao desespero, representando a cova negra o Inferno e o homem que o salva, a ajuda divina que a resistência do rei à tentação demoníaca, figurada na donzela, proporciona-lhe, surgindo depois o homem que o reconforta vindo pelo mar na barca de prata.

Uma nova tentação surge a Mordaim na rocha, repetindo-se os mesmos motivos. Desta vez, a bela donzela vinda na barca de vela preta, mente-lhe sobre o que se passou na sua terra durante a ausência rei, mas Mordaim resiste mais uma vez às propostas da donzela e a nave parte no meio de uma grande tempestade. Depois, um raio fende a rocha ${ }^{43}$. A cor da barca da donzela associa-a ao Inferno, sendo a esta uma figuração de um diabo, que deste modo tenta convencer o monarca a renunciar à fé cristã. De resto, também Nascião, perto do mar, depara-se, mais tarde, com uma donzela que acaba por se revelar ser um demónio, dando-se depois a transformação daquela neste.

\footnotetext{
${ }^{40}$ Ibidem, p.298.

${ }^{41}$ Ibidem, pp.176-178.

42 Ibidem, p. 178.

${ }^{43}$ Ibidem, pp.182-184.
} 
No que respeita a tentações demoníacas associadas ao preto, registamos ainda a que são sujeitos os enviados de Sargacinta, em busca do marido Nascião, e a donzela que no caminho encontraram. Estando sozinhos na ilha onde Hipócrates mandou construir um palácio e encontrando-se perdidos e desesperados, vêem surgir do mar uma velha e feia barca, na qual se encontra um homem de elevada estatura, feio e disforme, e de cor preta como o pez. Este promete salvá-los se lhe prestarem menagem, fazendo-o seu senhor e suserano, dizendo-lhes possuir grande poderio pois a maior parte dos homens o serve. Por fim, afirma chamar-se a serpente sisuda e promete-lhes riquezas e o usufruto de todos os prazeres mundanos que desejassem caso o quisessem seguir. Perante a recusa dos mensageiros e da donzela, profetiza-lhes a morte pela fome na ilha e que os seus corpos servirão de alimento a aves e bestas, acabando por os abandonar no meio de uma grande tempestade ${ }^{44}$. Estamos, assim, perante uma nova tentação do Demónio a fiéis de Cristo que acabam por recusar os prometidos prazeres terrenos, preferindo manter-se cristãos.

O preto surge assim associado ao Diabo e ao Inferno, sublinhando as tentações a que são sujeitos os fiéis, que acabam por lhe resistir. Assinalo ainda que quando Mordaim é impedido de comer o pão de cevada pela ave fabulosa de cabeça negra como o pez, a que já fiz referência, o alimento proibido que tenta o rei é, significativamente, negro ${ }^{45}$.

Esta também é a cor associada ao pecado. No sonho do duque Ganor os pombos que representam os fiéis baptizados que acompanham Josefes até à Grã-bretanha e que pecaram, nomeadamente ao não se manterem castos, ficam negros após passarem pela nuvem. Depois, dirigem-se para um vale negro, onde ficam retidos, e que simboliza, como é explicado pelo guardião do Graal, o Inferno.

O preto é também a cor da condenação e do castigo da justiça divina. Depois de Nascião ser evacuado da prisão pelas brancas mãos, Calafer, seu inimigo e responsável pela detenção do cavaleiro, é perseguido pela nuvem vermelha, da qual sai o pé que lhe marca a face esquerda de uma mancha negra que provoca frio, como se de geada se tratasse, enquanto na face direita, o sinal vermelho lhe inflinge a dor do fogo. Mais

\footnotetext{
${ }^{44}$ Ibidem, pp.263-265.

${ }^{45}$ Ibidem, p. 185.
} 
tarde, após a libertação de Celidones, também por mãos vindas do céu, uma repentina escuridão abate-se sobre a torre onde tinha estado preso, e ouve-se uma voz alertando os seguidores do crucifixo para fugirem pois chegou a vingança para os seus inimigos. De seguida, surge a tempestade cujos raios destroem a torre matando Calafer, que tinha mandado prender o filho de Nascião ${ }^{46}$. Deste modo, o preto é a cor que assinala a condenação eterna a que estão condenados os inimigos dos fiéis a Cristo, e os pecadores simbolizados pelos pombos no sonho do duque Ganor. À cor associa-se a escuridão que contrasta com o branco da cor das mãos que libertam Celidones e o pai e com a claridade do céu aberto que lhes surge depois de saírem das escuras prisões onde estiveram detidos.

Ora, no lado vermelho da espada que se encontra na nau de Salomão que aporta na ilha onde se encontrava Nascião, este vê nela escritas letras a preto que avisam que apenas a quem está destinada pode tocar-lhe, avisando que os outros incorrerão na punição divina se o fizerem. Quando Nascião a vira toda a nau treme pois não é a ele que a espada se destina. No outro lado, a espada ostenta, significativamente, a cor negra como o pez, não permitindo a Nascião verificar de que material a arma era feita ${ }^{47}$. Assim, o preto associa-se ao aviso que alerta para o perigo de uma possível condenação por parte da divindade aos que não seguirem as suas intenções, protegendo assim os sagrados objectos da nau de Salomão.

Desta forma, no Livro de José de Arimateia o preto é a cor da condenação eterna que envia para o Inferno os inimigos dos cristãos ou os que desafiam a autoridade divina, sendo também a marca do pecado e da vingança de Deus, assim como a cor que se reporta ao Inferno e aos seus seres e os caracteriza.

Finalmente, surge referenciada em duas ocasiões a cor azul. No entanto, o narrador não nos explicita o seu simbolismo no texto, como faz ou sugere, para as cores até agora analisadas. Penso, no entanto, que é possível adiantar possíveis significados para a cor, enquadrados nos momentos da narrativa em que o azul é citado.

\footnotetext{
${ }^{46}$ Ibidem, p. 195.

${ }^{47}$ Ibidem, p.208.
} 
Este surge sempre associado ao dourado, a letras em ouro. Desta forma na visão do rei Evalac que referimos, em que surgem as três árvores que simbolizam a Trindade, em cada uma estão inscritas letras "em ouro", azuis e vermelhas, dizendo na primeira "este forma", numa referência ao Deus pai, criador do mundo e dos homens, na outra "este salva", ou seja, Cristo que redimiu a humanidade, e na terceira "este limpa" numa referência ao Espírito Santo ${ }^{48}$. Ora o dourado é a cor da divindade que remete para a soberania de Deus e ao seu poder, que atravessa o céu como os amarelos raios do sol $^{49}$, enquanto o vermelho remete para Cristo, lembrando o sangue por ele derramado na cruz. Quanto ao azul, ele é também uma cor associada à divindade, nomeadamente ao remeter para o infinito, para a pureza, para o firmamento e para o céu ${ }^{50}$, e, portanto, para os seres que o habitam. $\mathrm{O}$ azul surge simbolicamente associado ao branco como as cores do céu que se opõem às cores da terra ${ }^{51}$. Penso que no caso das letras do texto, em função do que referimos, elas remetem para a Trindade, tal como os ramos brancos que as ostentam, uma vez que o azul e o dourado simbolizam a divindade celeste que vela, rege e orienta os homens para a sua devoção, pelo que se associam simbolicamente ao Pai e ao Espírito Santo, enquanto o vermelho remete para o Filho que redimiu e salvou a humanidade.

Na segunda referência ao azul, este transmite uma simbologia diferente. Na verdade, é a cor, juntamente, e de novo, com o dourado, das letras que se encontram na bainha da espada de cor vermelha. Depois de referir quem pode utilizar a arma e de ameaçar os outros que o tentem, o texto inscrito na bainha refere-se à donzela, filha de reis que a irá desembainhar ${ }^{52}$. Ora, na Demanda do Santo Graal, surge a virgem, destinada a tirar a espada da bainha e que a entrega a Galaaz e que, como se encontra explícito pelas letras da espada, é de sangue real. Ora é ela que substitui a frágil cinta da espada, feita de estopa e cânhamo, por uma feita dos seus cabelos. Penso que as cores vermelha, azul e dourada, que surgem de novo associadas, agora num contexto diferente, remetem para simbologias distintas das que propus no parágrafo anterior. Neste caso, o vermelho tanto pode ser identificado como a cor da nova fé, como reportar-se, tal como

\footnotetext{
${ }^{48}$ Ibidem, p. 107.

${ }^{49}$ Jean Chevalier, Alain Gheerbrant, Dicionário dos Símbolos, Lisboa, Editorial Teorema, s.d., pp.58,59.

${ }^{50}$ Gerd Heinz-Mohr, Op. cit., pp.338,339; Jean Chevalier, Alain Gheerbrant, Op. cit., pp.105-107.

${ }^{51}$ Gerd Heinz-Mohr, Op. cit., p.338.

${ }^{52}$ O Livro de José de Arimateia, pp.207,208.
} 
anteriormente referi, à justiça divina a que ficam sujeitos os que não obedecerem ao que se encontra escrito na bainha. No caso do dourado e do azul, elas reportam-se à donzela referida nas letras, uma vez que o dourado é identificado com a cor da realeza terrena, cujo poder é sancionado por Deus ${ }^{53}$, e o azul é a cor associado à Virgem, que nas representações medievais ostenta um manto azul e reporta-se à cor do céu durante a ascensão de Maria ${ }^{54}$. O azul foi assim identificado com a virgindade, tal como o branco, ao reportar-se à mãe de Jesus ${ }^{55}$. Sendo assim, as cores das letras referem-se simbolicamente aos atributos que caracterizam a donzela destinada a desembainhar a espada, filha de rei e rainha e virgem.

Portanto, proponho que no Livro de José de Arimateia, a cor azul seja a cor que simboliza, quer a divindade celeste, quer, conjuntamente com o branco, a virgindade, enquanto o dourado que lhe surge associado remete para Deus e para o poder terreno por Ele sancionado.

Por fim, resta-me assinalar que também se encontram referidas cores no trajecto inicial do narrador, nomeadamente quando este relata a sua viagem com a besta compósita. Tanto na descrição desta, como na da fonte amarga, o narrador refere as cores que se lhes encontram associadas. No entanto, optei por não as analisar, adiando para um futuro estudo a abordagem ao percurso iniciático do narrador, antes de escrever o texto que lhe foi transmitido pela divindade. Tal justifica-se pelo facto de não me ter satisfeito a primeira abordagem que fiz a este relato, pelo que as propostas que poderia adiantar para as simbologias das cores seriam meramente hipotéticas, sem as bases justificativas que se podem aplicar na análise das cores na restante narrativa do Livro de José de Arimateia.

Concluindo, o texto que constitui a primeira parte do ciclo da Pós-Vulgata é marcadamente simbólico e onde o imaginário de origem celta, bem presente nas ilhas, nas viagens por mar e nos animais referenciados, se encontra já profundamente cristianizado, tendo sido de resto considerada uma narrativa hagiográfica na Idade Média. As cores que surgem na narrativa transmitem, assim, significados simbólicos

\footnotetext{
${ }^{53}$ Jean Chevalier, Alain Gheerbrant, Op. cit., p.58.

${ }^{54}$ Gerd Heinz-Mohr, Op. cit., pp.338,339.

${ }^{55}$ Jean Chevalier, Alain Gheerbrant, Op. cit., p.106.
} 
que orientam o leitor na sua leitura e interpretação, nomeadamente, ao reforçar, pela sua significação simbólico-alegórica, o sentido que o autor quis transmitir ao Livro de José de Arimateia.

Como pudemos constatar, é sobretudo para o imaginário cristão que as cores reenviam. Tratando-se do relato do transporte de Jerusalém para a Grã Bretanha do cálice que conteria o sangue de Cristo e da formação de uma nova cavalaria, orientada pelos princípios cristãos, narrando-se ainda a sagração do primeiro bispo da Cristandade, o texto do Livro transmite uma forte componente mística que tem como universo de referência o Cristianismo e os seus textos sagrados, encontrando-se portando, como atrás referi, a história do Graal já cristianizada, não obstante e, como referimos, ainda se detectar na narrativa os elementos pagãos que se encontram na sua génese.

As cores referidas no Livro são o branco, o vermelho, o verde, o azul e, ainda, a "cor do ouro", ou seja, o dourado. Através da análise da sua presença na narrativa tentei contribuir para o estudo de um texto que, salvo raras excepções, não tem tido a divulgação e atenção que merece. Por outro lado, penso que será interessante comparar as simbologias das cores que propus com outras obras que as citem, assim, como com as transmitidas por outras formas de representação, como é o caso da iluminura. Também da análise da frequência com que cada cor é citada, poder-se-á alcançar resultados que podem ser pertinentes e importantes para a análise da presença das cores na produção das obras medievais que chegaram até nós.

\section{BIBLIOGRAFIA}

\section{Fonte:}


The Portuguese Book of Joseph of Arimathea, Carter, H., (ed.), Chapel Hill, The University of North Caroline Press, 1967.

\section{Fontes Auxiliares:}

A Demanda do Santo Graal, Nunes, I. F., (ed.), Lisboa, Imprensa Nacional-Casa da Moeda, 1995.

Livro de José de Arimateia: Estudo e Edição do Cód. A.N.T.T. 643, Castro, I., Dissertação de Doutoramento, Lisboa, Faculdade de Letras da Universidade Clássica de Lisboa, 1984.

\section{Estudos:}

CASTRO, Ivo, "Livro de José de Arimateia" in Dicionário da Literatura Medieval Galega e Portuguesa, Lanciani, G., Tavani, G., (dir.), Editorial Caminho, 1993, pp. 445-450.

"Matéria da Bretanha" in Dicionário da Literatura Medieval Galega e Portuguesa, Lanciani, G., Tavani, G., (dir.), Editorial Caminho, 1993, pp. 445-450.

«Sobre a data da introdução na Península Ibérica do ciclo arturiano da

Post-Vulgata», Boletim de Filologia, XXVIII, 1983, pp. 81-98.

CHAMBEL, Pedro, A Simbologia dos Animais n'"A Demanda do Santo Graal", Cascais, Patrimonia, 2000.

Os Animais na Literatura Clerical Medieval Portuguesa dos Séculos XIII e XIV- Presença e Funções”, Lisboa, dissertação de doutoramento, Faculdade de Ciências Sociais e .Humanas da U. N. L., 2003.

CHEVALIER, Jean, GHEERBRANT Alain, Dicionário dos Símbolos, Lisboa, Editorial Teorema, s.d.. 
HEINZ-MOHR, Gerd, Dicionário dos Símbolos - Imagens e Sinais da Arte Cristã, São Paulo, Paulus, 1994.

MEDEIROS, Ana, Aspectos do Bestiário no "Livro de José de Arimateia”, Lisboa, Faculdade de Letras de Lisboa, dissertação de. Mestrado, 2003.

MIRANDA, José Carlos, Conto de Perom, o melhor cavaleiro do mundo. Texto e comentário de uma narrativa do "Livro de José de Arimateia", versão portuguesa da “Estoire del Saint Graal”, Porto, Granito, 1998 (2 ed.)

"A Demanda do Santo Graal" e o Ciclo Arturiano da Vulgata, Porto, Granito, 1998

Galaaz e a ideologia da linhagem, Porto, Granito, 1998

\section{COMO CITAR ESTE ARTIGO}

\section{Referência electrónica:}

CHAMBEL, Pedro - "O Simbolismo das Cores no Livro de José de Arimateia".

Medievalista [Em linha]. No 10, (Julho de 2011). [Consultado dd.mm.aaaa]. Disponível em http://www2.fcsh.unl.pt/iem/medievalista/MEDIEVALISTA10lchambel1004.html. ISSN 1646-740X. 


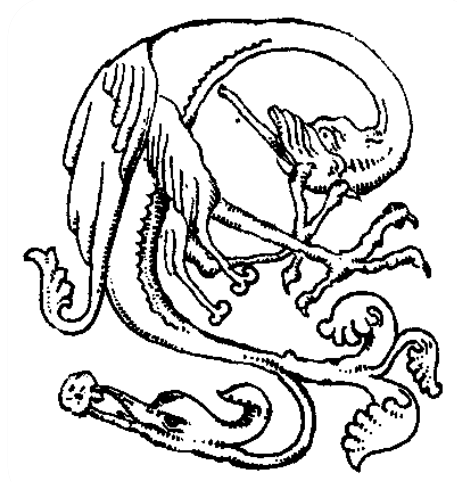

